\title{
College, Discipline, and Sex Factors Effecting Employment Opportunities for Graduates
}

\author{
Jun Kong \\ Dept. of Public Finance and Taxation \\ School of Economics and Management, Northwest University \\ Xi'an, China \\ Email: 544790789@qq.com
}

\begin{abstract}
This paper focuses on some factors that affect graduates' job opportunities which have been studied such as college, dicipline, and sex. A semi-parametric survival model for this study indicates that the graduates who are from research university find jobs faster. Moreover, the paper shows graduates with engineering and business deciplines obtain job position more easily. Finally, female graduates find jobs faster than male graduates. Some of results are different with previous studies from the whole area of Beijing.
\end{abstract}

Keyword-factors; employment opportunity; graduate's job search

\section{INTRODUCTION}

In this paper, a semi-parametric survival model is used to analyze Chinese graduates' unemployment spell effected by reputation of university, decipline, and sex. Previous work is not clear for these factors affecting job search. One paper suggests that reputation of university has the significant effect on the graduates' job search in England, and Bradley and Nguyen (2004) show that school quality has a much larger effect than academic performance on the transition of school-to-labor in England. However, Zhou (2003) uses graduate samples in China and finds that reputation of college has only a small positive effect on graduates' finding jobs.

Regarding sex, Bradley and Nguyen (2004) present the males from high quality schools are less likely to enter the labor market compared to the females in England. They are more likely to stay unemployed. Bratberg and Nilsen (1998) present female graduates in Norway entering the labor market ahead of males. Ghazala (2006) finds that sex gaps in unemployment rates have risen in the past 20 years in many European countries. However, Zhou (2003) reveals that male graduates find jobs more easily than female graduates in China. Min et al.(2006) also show the percentage of male graduates signing job contracts is higher than female's figure.

In U.S., Harrington and Simpson (1983) attribute the higher unemployment to inadequate educational attainment. Norman (1984) reveals that the American graduates in the late 1960 's were $30 \%$ more likely to be employed than dropouts. Wolpin (1987) argues that higher reservation wages lead to a longer duration of unemployment in U.S. This implies that the graduates may have a longer unemployment spell when they are from better colleges with higher expected wages. Stern (1989) demonstrates that college graduates accepted larger offers than that of dropouts during the same period.
Eckstein and Wolpin (1995) find that differences in unemployment duration by schooling in United States are primarily due to differential rates at which job offers are accepted rather than differential job-offer probabilities. Bjorklund and Eriksson (1996) study the case of the Nordic countries and indicate a lower unemployment rate for workers with high education than those with low education. Bratberg and Nilsen (1998) demonstrate that individuals with a higher level of education have the longer first job duration.

The contribution of this paper lies in that a nonparametric survival analysis has been applied to the factors that affect new graduate's job search. Previous researches often use logistic model to analyze job search from Bratberg and Nilsen (1998), Zhou (2003) and Min et al. (2006). Moreover, this paper finds female graduates find jobs faster. This is different from previous results by Zhou (2003) and Min et al. (2006).

\section{SUMMARY STATISTICS}

This paper classifies categories of university into research university, ordinary university, and college. Deciplines cover liberal arts and social science, science, engineering, law, medicine, agriculture, and business. Sex refers to female and male graduates.

Table 1 provides descriptive statistics on university type, decipline, sex, and average duration of unemployment. Research university's percentage of employment reaches $92.62 \%$ of total number. The employed percentages of other two types of college are $93.60 \%$ and $89.46 \%$ respectively. Secondly, Most graduates with employment are from deciplines of liberal arts and social science, engineering and business. Their numbers are 2,034, 2,220 and 2,052 respectively of total employment at 7,619. Furthermore, the number of employed female graduates reaches 3,899 which are slightly more than the number of male graduates at 3,720 .

In addition, this paper defines base time of survival function at 6 months before graduation. The graduates from research universities and ordinary universities have the shorter average duration of unemployment, which are 7.22 and 7.10 months, compared to the number of colleges, which is 7.56 months, means 1.56 months after graduation. From the view of decipline classification, the business graduates own the shorter average duration of unemployment, which are 6.97 months, compared to the figure from deciplines of law and engineering, which are 7.31 and 7.33 months. Meanwhile, the average durations of 
unemployment from liberal arts and social science, science, agriculture and medicine are in middle place. Moreover, females have a shorter average duration of unemployment, which is 7.14 months, compared to male's 7.26 months.

Table 2 shows numbers of the employed and the unemployed during the discrete unemployment spell. Most cases for employment occur during the 6,7 and 8 months. There are cases in dataset of some students who have entered the labor market before graduation.

TABLE 1. AVERAGE DURATION OF UNEMPLOYMENT

\begin{tabular}{|l|l|l|l|}
\hline \multicolumn{1}{|c|}{ Variables } & \multicolumn{1}{|c|}{$\begin{array}{c}\text { The Employed } \\
\text { Number }\end{array}$} & \multicolumn{1}{|c|}{$\begin{array}{c}\text { The Unemployed } \\
\text { Number }\end{array}$} & $\begin{array}{l}\text { Average } \\
\text { Duration }\end{array}$ \\
\hline $\begin{array}{l}\text { Research } \\
\text { University }\end{array}$ & 4,406 & 351 & $\begin{array}{l}7.22 \\
(0.036)\end{array}$ \\
\hline $\begin{array}{l}\text { Ordinary } \\
\text { University }\end{array}$ & 2,763 & 189 & $\begin{array}{l}7.10 \\
(0.058)\end{array}$ \\
\hline College & 450 & 53 & $\begin{array}{l}7.56 \\
(0.152)\end{array}$ \\
\hline $\begin{array}{l}\text { Liberal arts and } \\
\text { social science }\end{array}$ & 2,034 & 154 & $\begin{array}{l}7.25 \\
(0.064)\end{array}$ \\
\hline Law & 562 & 81 & $\begin{array}{l}7.31 \\
(0.119)\end{array}$ \\
\hline Science & 586 & 82 & $\begin{array}{l}7.23 \\
(0.107)\end{array}$ \\
\hline Engineering & 2,220 & 131 & $\begin{array}{l}7.33 \\
(0.052)\end{array}$ \\
\hline Agriculture & 93 & 7 & $\begin{array}{l}7 \\
(0.266)\end{array}$ \\
\hline Medicine & 72 & 8 & $\begin{array}{l}7.19 \\
(0.284)\end{array}$ \\
\hline Business & 2,052 & 130 & $\begin{array}{l}6.97 \\
(0.062)\end{array}$ \\
\hline Female & 3,899 & 284 & $\begin{array}{l}7.14 \\
(0.045)\end{array}$ \\
\hline Male & 3,720 & 309 & $\begin{array}{l}7.26 \\
(0.042)\end{array}$ \\
\hline
\end{tabular}

Notes:The figures in parentheses refer to standard error.

TABLE 2. Numbers AND PERCENTAGe OF EMPLOYMENT, AND UNEMPLOYMENT SPELL

\begin{tabular}{|l|l|l|}
\hline Unemployment Spell & Employment & Unemployment \\
\hline 0 & 0 & 8,212 \\
\hline 1 & 171 & 8,041 \\
\hline 2 & 277 & 7,764 \\
\hline 3 & 303 & 7,461 \\
\hline 4 & 298 & 7,163 \\
\hline 5 & 360 & 6.803 \\
\hline 6 & 1,223 & 5,580 \\
\hline 7 & 1,950 & 3,630 \\
\hline 8 & 1,323 & 2,307 \\
\hline 9 & 553 & 1,754 \\
\hline 10 & 317 & 1,437 \\
\hline 11 & 266 & 1,171 \\
\hline 12 & 223 & 948 \\
\hline 13 & 144 & 804 \\
\hline 14 & 146 & 658 \\
\hline 15 & 58 & 600 \\
\hline 16 & 7 & 593 \\
\hline Total & 7,619 & \\
\hline & & \\
\hline
\end{tabular}

\section{EMPIRICAL MODEL AND ESTIMATION}

\section{A. The Empirical Model}

A semi-parametric survival model (SPSM) is used to analyze the factors that affect the unemployment spell. The SPSM can be defined by:

$$
\operatorname{Ln}[h(t)]=\operatorname{Ln}\left[h_{0}(t)\right]+\beta_{i} X_{i}+\varepsilon_{i}
$$

The unemployment spell, namely, $t$ starts from 6 months before graduation, $h(t)$ is the hazard rate for failure, $h_{0}(t)$ is base hazard rate. $\beta_{i}$ are coefficients of explanatory variables that affect $t \cdot \varepsilon_{i}$ is random variable with a standard distribution, and $X_{i}$ stands for explanatory variables including reputation, decipline and sex.

\section{B. Estimation Results}

In SPSM, the Cox proportional hazard model is used to analyze what factors affecting unemployment spell. From the analysis of the Cox proportional hazard model in Table 3, The hazard rates for research universities and ordinary universities are 1.20 and 1.22 respectively compared to 1 , which is the figure for colleges. This outcome indicates faster job finding for the graduates from research universities and ordinary universities. The hazard rate for engineering graduates, which is comparison variable, is greater than that of liberal arts and social science, law, science at 5\% significant level. There are no significant different effects between engineering and business as well as between engineering and agriculture, engineering and medicine. The female graduates' hazard rate is more than that of male graduates, and shows them finding jobs faster. In addition, proportionality of hazard rate is tested in Table 4, Table 5, and Table 6. To do this, the paper generates the time dependent covariates by creating interactions of the factors and a function of unemployment spell that included in the Cox model. Those factors are not proportional if any of the time dependent covariates are significant. From Table 4, the result indicates that hazard rates of reputation of university are not proportional because high reputation of university of the unemployment-time dependent covariate is significant at $1 \%$ level. From Table 5, liberal arts and social science, law, and science of the unemployment-time dependent covariates are significant at $1 \%$ level. This shows that hazard rates of deciplines are not proportional. Table 6 also shows same result that hazard rates of sex are not proportional.

TABLE 3. OUTCOME OF REGRESSION BY COX PROPORTIONAL HAZARD MODEL

\begin{tabular}{|l|l|l|l|l|}
\hline \multicolumn{1}{|c|}{ Variables } & Haz. Ratio & Std. Err & \multicolumn{1}{|c|}{$\mathbf{z}$} & $\mathbf{P}>\mid \mathbf{z}$ \\
\hline Research University & 1.20 & 0.060 & 3.71 & 0.000 \\
\hline Ordinary University & 1.22 & 0.063 & 3.85 & 0.000 \\
\hline Liberal arts and social science & .941 & 0.030 & -1.88 & 0.060 \\
\hline Law & .810 & 0.039 & -4.39 & 0.000 \\
\hline Science & .864 & 0.040 & -3.13 & 0.002 \\
\hline Agriculture & 1.03 & 0.109 & 0.28 & 0.783 \\
\hline Medicine & .894 & 0.107 & -0.93 & 0.352 \\
\hline Business & 1.05 & 0.033 & 1.63 & 0.104 \\
\hline Female Graduates & 1.05 & 0.025 & 2.07 & 0.038 \\
\hline
\end{tabular}

TABLE 4. TEST OF PROPORTIONALITY FOR REPUTATION OF UNIVERSITY

\begin{tabular}{|l|l|l|l|l|}
\hline \multicolumn{1}{|c|}{$\_t$} & \multicolumn{1}{|c|}{ Coefficient } & Std. & Err. & $\mathbf{z}$ \\
\hline main & & & & \\
\hline Research University & -0.339 & 0194 & -1.75 & 0.080 \\
\hline Ordinary University & 0.307 & 0.195 & 1.57 & 0.116 \\
\hline Tvc & & & & \\
\hline Research University & 0.264 & 0.098 & 2.69 & 0.007 \\
\hline Ordinary University & -0.064 & 0.099 & -0.65 & 0.516 \\
\hline
\end{tabular}

Note: Variables in tvc equation interacted with unemployment spell. 
TABLE 5. TEST OF PROPORTIONALITY FOR DECIPLINE

\begin{tabular}{|l|l|l|l|l|}
\hline $\mathbf{t}$ & Coefficient & Std. & Err. & $\mathbf{z}$ \\
\hline main & & & & \\
\hline $\begin{array}{l}\text { Liberal arts } \\
\text { and social } \\
\text { science }\end{array}$ & 0.572 & 0.132 & 4.34 & 0.000 \\
\hline Law & 0.610 & 0.189 & 3.23 & 0.001 \\
\hline Science & 0.480 & 0.190 & 2.52 & 0.012 \\
\hline Agriculture & 0.371 & 0.440 & 0.84 & 0.399 \\
\hline Medicine & 0.513 & 0.483 & 1.06 & 0.288 \\
\hline Business & 0.806 & 0.128 & 6.29 & 0.000 \\
\hline Tvc arts & & & & \\
\hline $\begin{array}{l}\text { Liberal and social } \\
\text { and } \\
\text { science }\end{array}$ & -0.322 & 0.067 & -4.78 & 0.000 \\
\hline Law & -0.421 & 0.096 & -4.36 & 0.000 \\
\hline Science & -.332 & .097 & -3.42 & 0.001 \\
\hline Agriculture & -.178 & .227 & -0.78 & 0.433 \\
\hline Medicine & -.333 & .249 & -1.33 & 0.182 \\
\hline Business & -.396 & .066 & -6.00 & 0.000 \\
\hline
\end{tabular}

Note: Variables in tvc equation interacted with unemployment spell.

TABLE 6. TEST OF PROPORTIONALITY FOR SEX

\begin{tabular}{|l|l|l|l|l|}
\hline \multicolumn{1}{|c|}{ Ct } & \multicolumn{1}{c|}{ Coefficient } & Std. & Err. & z \\
\hline main & & & & \\
\hline Female Graduate & .325 & .093 & 3.51 & 0.000 \\
\hline Tvc & & & & \\
\hline Female Graduate & -.148 & .048 & -3.09 & 0.002 \\
\hline
\end{tabular}

Note: Variables in tvc equation interacted with unemployment spell.

\section{CONCLUSION}

This paper outlines the factors affecting graduate unemployment spell. It is therefore concluded that firstly, female graduates begin to work earlier. This result is different from previous studies that male graduates find jobs more successfully in China. Secondly, graduates from colleges with better reputation are more successful in their job search. This outcome is different from Zhou's studies that indicate reputation only has slight effect on job search, but is same as previous outcomes studied from other countries. Finally, engineering and business graduates find jobs more easily, and law and science graduates find jobs more difficult. This is also similar to previous studies that mention law graduates find job more difficult in China.

\section{REFERENCES}

[1] Bradley, S. and A. N. Nguyen, The School-to-Work Transition, International Handbook of Education Economics, Cheltenham, (pp.484-521): Edward Elgar (Eds G. Johnes and J. Johnes). 2004

[2] Zhou, Jun Bo, A Study on Graduates' Costs in Job Hunting, Economics of Education Research (Beida), vol.1(1), pp.12-20, 2003. (in Chinese)

[3] Bratberg, E. and O. A. Nilsen, Transitions from School to Work: Search Time and Job Duration, IZA, DP, No.27, pp.1-29, 1998.

[4] Ghazala Azmat, Maia Guell and Alan Manning, Sex Gaps in Unemployment Rates in OECD Countries, Journal of Labor Economics, vol.24(1), pp.1-38, 2006.

[5] Min Weifang, Ding Xiaohao, Wen Dongmao and Yue Dongchang, The Survey on the College Graduates in 2005, Guan Ming Observation, vol.3, pp.13-26, 2006. (in Chinese)

[6] Sum, Harrington and Simpson, Educational Attainment, Academic Ability, and the Employability and Earnings of Young Persons: Implications for the Planning and Design of JTPA Youth Programs, Boston, MA: Northeastern University, Center for labor Market Studies, 1983.
[7] Norman Freeberg, Factors Affecting Job Search Behavior and Employment Outcome for Youth, Final Technical Report, Educational Testing Service, Princeton, N.J. 1984.

[8] Wolpin KI, Estimating a Structural Search Model: The Transition from School to Work, Econometrica,vol.55(4),801-17, 1987.

[9] Steven Stern, Estimating a Simultaneous Search Model, Journal of Labor Economics, vol.7(3), 348-369, 1989.

[10] Eckstein Z, Wolpin KI, Duration to First Job and the Return to Schooling: Estimates from a Search-Matching Model, Review of Economic Studies vol. 62(2), pp.263-86, 1995.

[11] Bjorklund, Anders and Eriksson, Tor, Unemployment in the Nordic Countries, In The Nordic Labour Markets in the 1990's, (pp.96-116), edited by Eskil Wadensjo, Amsterdam: Elsevier, 1996. 